\title{
АНАЛІЗ СТАНУ ПРОФІЛАКТИКИ ПЕРЕДАЧІ ВІЛ ВІД МАТЕРІ ДО ДИТИНИ
}

\author{
${ }^{1}$ ДУ "Український інститут стратегічних досліджень МОЗ України”, м. Київ \\ ${ }^{2}$ Національна медична академія післядипломної освіти імені П.Л. Шупика, м. Київ, Україна \\ ${ }^{3}$ Міністерство охорони здоров'я України, м. Київ
}

\begin{abstract}
Мета: визначити стан системи профілактики передачі ВІЛ від матері до дитини, заходів з планування сім'ї для ВІЛ-інфікованих жінок.

Матеріали і методи. У дослідженні вивчалися матеріали медичної та статистичної документації, використані статистичний, аналітичний, організаційний та концептуальний методи.

Результати. Встановлено, що основними проблемами передачі ВІЛ від матері до дитини в Україні $\epsilon$ непланованість вагітності та пов'язана з цим низька прихильність до своєчасного обстеження на ВІЛ, допологового нагляду, APB-профрілактики під час вагітності, своєчасної госпіталізації на пологи, обстеження новонародженого та оптимального догляду за ним; пізні стадії ВІЛ-інфекції у вагітних; споживання ін'єкційних наркотиків; ризикована статева поведінка під час вагітності.

Висновки. Профрілактику вертикальної передачі ВІЛ в Україні можливо суттєво покращити за рахунок оптимізації діяльності служби планування сім'ї та покращення надання медико-соціальної допомоги ВІЛ-інсрікованим жінкам.

КЛЮЧОВІ СЛОВА: ВІЛ-інфрекція, планування сім'ї, жінки, діти, профрілактика передачі ВІЛ від матері до дитини.
\end{abstract}

Передача ВІЛ від матері до дитини (ПМД) - один із шляхів поширення збудника ВІЛ-інорекції, що превалює серед інших причин інфрікування ВІЛ дітей молодшого віку. Своєчасна, комплексна та послідовна профрілактика передачі ВІЛ від матері до дитини (ППМД) дозволяє суттєво вплинути на цей шлях інфікування ВІЛ з перспективою максимального його обмеження. Недостатня прихильність ВІЛ-інфрікованих вагітних до антиретровірусної профрілактики, як наслідок небажаної вагітності, $€$ суттєвою причиною ПМД, що вказує на актуальність питання планування сім'ї у ВІЛ-інфікованих вагітних.

Мета роботи: визначення основних складових системи профрілактики передачі ВІЛ від матері до дитини.

Матеріали і методи. У ході дослідження використано статистичний, аналітичний, організаційний та концептуальний методи.

Результати дослідження та їх обговорення. Починаючи 32001 р., Україна досягла значного прогресу у сорері ППМД. Реалізація національної стратегії програми ППМД - це єдине профрілактичне втручання в Україні, що охопило більшу частину своєї цільової групи високоякісними заходами та призвело до зниження показника частоти передачі ВІЛ від матері до дитини (ЧПМД) [6]. Проте в Україні щорічно реєструється біля 170-200 ВІЛ- інфрікованих дітей, народжених ВІЛ-інфікованими матерями [2]. Так, у 2014 р. в країні зареєстровано понад 2728 ВІЛ-позитивних вагітних, показник ВІЛінфрікованих на 100 вагітних становив 0,62\% [2].

Сучасні тенденції розвитку епідемічного процесу ВІЛ-інфекції свідчать, що на тлі «фремінізації» епідемії, яка характеризується збільшенням частки ВІЛ-інфрікованих жінок серед загальної кількості ВІЛ-інфікованих пацієнтів (3 43,6\% у 2010 р. до 44,2\% у 2014 р.) та статевого шляху передачі ВІЛ-інфекції, який став домінуючим для жінок з 2007 р. (3 55,5\% у 2010 р. до $69,2 \%$ у 2014 р.), очікується подальше зростання кількості дітей, народжених ВІЛ-інфікованими жінками, що потребує удосконалення заходів у сорері ППМД, зокрема заходів з планування сім'ї, що сприяють зменшенню кількості непланованих вагітностей, за якими ВІЛ-інфріковані вагітні не схильні або недостатньо схильні до антиретровірусної профрілактики (АРВпрофрілактики), що впливає на збільшення кількості дітей з перинатальною ВІЛ-інфекцією [2].

У рамках глобальної стратегії Об'єднаної програми Організації Об'єднаних Націй 3 ВІЛ/СНІДу (ЮНЕЙДС) та Всесвітньої організації охорони здоров'я (ВОО3) щодо повного викорінення ПМД Україна, поряд з іншими країнами - членами ООН, зобов'язалась зміцнювати та розширювати програми ППМД до 2015 року [4-6]. Профрілактика 
вертикальної трансмісії ВІЛ-інфекції має декілька складових та насамперед залежить від рівня виявлення ВІЛ-інфекції у вагітних.

Рівень обстеження вагітних на ВІЛ визначає своєчасність та повноту профрілактики ВІЛ-інфекції у новонароджених. Тестування на ВІЛ здійснюється усім вагітним за їх поінфрормованою письмовою згодою. Стандартне тестування крові вагітної на ВІЛ здійснюється при взятті на облік. У разі встановлення діагнозу ВІЛ-інфекції повторне обстеження не призначається, а проводяться відразу заходи із запобігання вертикальної трансмісії ВІЛ. Відповідно до спільного наказу Міністерства охорони здоров'я України, Міністерства освіти і науки України, Міністерства України у справах сім “ї, молоді та спорту, Державного департаменту України 3 питань виконання покарань та Міністерства праці та соціальної політики України від 23.11.2007 № 740/1030/4154/321/614a «Про заходи щодо організації профрілактики передачі ВІЛ від матері до дитини, медичної допомоги і соціального супроводу ВІЛ-інфікованих дітей та їх сімей», у разі отримання негативного результату на ВІЛ методом імуноферментного аналізу (ІФА) при взятті на облік до 12 тижнів вагітності повторне тестування проводиться у терміні вагітності 22-23 тижні. У разі виявлення ВІЛ-інфекції вагітній призначається медикаментозна профрілактика вертикальної трансмісії ВІЛ відповідно до клінічного протоколу. У разі отримання сумнівного результату обстеження методом ІФА до 23 тижнів вагітності вагітній призначається повторне тестування 3 використанням імунного блоту. Якщо вагітна взята на облік у зв'язку з вагітністю після 23-го тижня вагітності, їй призначається тестування крові на ВІЛ методом ІФА. У разі отримання негативного результату здійснюється повторне обстеження на ВІЛ не пізніше 32-го тижня вагітності. У разі взяття вагітної на облік у зв'язку 3 вагітністю пізніше 30 тижнів вагітності їй призначається тестування на ВІЛ методом ІФА або експрес-методом. У разі отримання негативного результату повторне обстеження проводиться експрес-методом у пологах.

Рівень обстеження вагітних на ВІЛ протягом останніх років утримується на достатньо високому рівні (85-99\%). У 2014 р. обстежено на ВІЛ 439795 вагітних, що становить 99,2\% від загальної кількості вагітних, які звернулись до лікаря-акушерагінеколога. Плановим методом дворазово обстежено 429404 вагітних (96,9\%). У Кіровоградській області показник обстеження вагітних на ВІЛ складає 100\%, у більшості областей рівень обстеження перевищує 99,0\%. Найнижчий показник зареєстрований у 2014 р. у Дніпропетровській області - 97,25\%. Недообстеження вагітних на ВІЛ не дає можливості призначити APB-профрілактику, що спричинює випадки перинатального ВІЛ-інфікування. Наведені у таблиці дані свідчать про необхідність підвищення рівня обстеження вагітних на ВІЛ-інфрекцію до 100\% для застосування методів третього компоненту ППМД у повному обсязі: проведення медикаментозної профрілактики (МП), родорозрішення шляхом операції кесарева розтину, виключення інвазивних втручань у пологах, виключення грудного вигодовування дитини, народженої ВІЛ-інфрікованою матір'ю [3].

Частка жінок, які дізналися про свій ВІЛпозитивний статус під час пологів, становила 4,9\%, а серед вагітних, що споживають ін'єкційні наркотики (ClH), даний показник дорівнював 18,0\%. Дізналися про свій ВІЛ-позитивний статус після пологів 4,2\% жінок, а серед жінок-СІН їхня частка була значно вищою - 11,8\%. Отримані дані, 3 одного боку, свідчать, що ВІЛ-інфріковані вагітні, які $€$ $\mathrm{CIH}$, все ще залишаються важкодоступною групою для проведення втручань 3 метою попередження вертикальної трансмісії ВІЛ, що негативно впливає на частоту передачі ВІЛ від матері до дитини, з іншого - ці показники свідчать, ймовірно, про небажану вагітність у цієї категорії жінок.

Одним з основних профрілактичних заходів перинатальної ВІЛ-інфрекції $€$ МП вертикальної трансмісії ВІЛ від матері до дитини, яка в Україні проводиться відповідно до клінічного протоколу «Попередження передачі ВІЛ від матері до дитини», затвердженого наказом МОЗ України від 14.11.2007 № 716, який розроблений за нашої участі. Цим протоколом 3 метою підвищення ефективності затверджений метод трикомпонентної МП (три АРВпрепарати) 3 24-26 тижнів вагітності.

Розширення масштабів послуг з ППМД протягом 2010-2014 рр. дозволило досягти високих рівнів показників охоплення ВІЛ-позитивних вагітних АРВ-профрілактикою (3 94,9\% у 2010 р. до $96,2 \%$ у 2014 р.), обстеженнями із визначення кількості CD4-лімфоцитів (3 68,9\% у 2010 р. до 95,6\% у 2014 р.) та рівня вірусного навантаження ВІЛ у плазмі крові (3 64,1\% у 2010 р. до 94,0\% у 2014 р.). В Україні зростає частка ВІЛ-позитивних вагітних, які отримують потрійну АРВ-профрілактику: 82,6\% - y 2011 p., $87,3 \%$ - y 2012 р., 90,4\% - y 2013 р., $96,2 \%$ - у 2014 році.

Кількість ВІЛ-інфікованих вагітних, які отримали АРВ-профрілактику, від загальної кількості ВІЛінфрікованих вагітних, у яких вагітність завершилася пологами, у 2014 р. становила 96,2\%, у тому числі АРТ за станом здоров'я вагітної - 40,6\%, AРВ-профрілактика - 50,7\% (трьома препаратами - 49,8\%), АРВ-профрілактика під час пологів (разова доза невірапіну) - 4,9\%. Привертає увагу, що майже половину становлять вагітні, які отримували АРТ за станом здоров'я, що свідчить про ускладнений перебіг ВІЛ-інфекції та про підвищений ризик вертикальної трансмісії ВІЛ. Адже загальновідомо, що при ускладненому перебігу ВІЛінфекції ризик ВІЛ-інфікування значно вищий, ніж 
Таблиця. Рівень обстеження вагітних на ВІЛ (2014р.)

\begin{tabular}{|c|c|c|c|c|c|c|}
\hline \multirow{2}{*}{$\begin{array}{c}\text { Адміністративна } \\
\text { територія }\end{array}$} & \multicolumn{2}{|r|}{ Усього } & \multicolumn{2}{|c|}{ У т.ч. двічі } & \multicolumn{2}{|c|}{ Позитивний ВІЛ-статус } \\
\hline & абс. & на 100 вагітних & абс. & на 100 вагітних & абс. & на 100 вагітних \\
\hline Україна & 439795 & 99,19 & 429404 & 96,85 & 2728 & 0,62 \\
\hline \multicolumn{7}{|l|}{ Область } \\
\hline Вінницька & 16532 & 99,46 & 16037 & 96,49 & 69 & 0,42 \\
\hline Волинська & 13574 & 99,16 & 13209 & 96,49 & 40 & 0,29 \\
\hline Дніпропетровська & 36261 & 97,25 & 34924 & 93,67 & 426 & 1,14 \\
\hline Донецька & 16525 & 98,45 & 15937 & 94,95 & 201 & 1,20 \\
\hline Житомирська & 14402 & 99,98 & 13905 & 96,53 & 79 & 0,55 \\
\hline Закарпатська & 17837 & 98,56 & 17414 & 96,22 & 12 & 0,07 \\
\hline Запорізька & 18383 & 98,53 & 16708 & 89,55 & 68 & 0,36 \\
\hline Івано-Франківська & 17050 & 99,77 & 16867 & 98,70 & 20 & 0,12 \\
\hline Київська & 20363 & 98,73 & 19921 & 96,59 & 147 & 0,71 \\
\hline Кіровоградська & 9935 & 100,00 & 9935 & 100,00 & 103 & 1,04 \\
\hline Луганська & 16838 & 98,83 & 16565 & 97,22 & 280 & 1,64 \\
\hline Львівська & 30237 & 99,98 & 29904 & 98,88 & 54 & 0,18 \\
\hline Миколаївська & 12440 & 99,25 & 12105 & 96,58 & 170 & 1,36 \\
\hline Одеська & 29159 & 99,30 & 28803 & 98,08 & 342 & 1,16 \\
\hline Полтавська & 14342 & 99,80 & 13786 & 95,93 & 85 & 0,59 \\
\hline Рівненська & 17031 & 99,87 & 16767 & 98,32 & 55 & 0,32 \\
\hline Сумська & 10175 & 99,98 & 10023 & 98,49 & 30 & 0,29 \\
\hline Тернопільська & 11345 & 99,67 & 11128 & 97,77 & 23 & 0,20 \\
\hline Харківська & 26657 & 99,82 & 26014 & 97,41 & 53 & 0,20 \\
\hline Херсонська & 11789 & 99,89 & 11598 & 98,27 & 91 & 0,77 \\
\hline Хмельницька & 13961 & 99,47 & 13793 & 98,27 & 46 & 0,33 \\
\hline Черкаська & 12133 & 99,72 & 11777 & 96,79 & 102 & 0,84 \\
\hline Чернівецька & 11764 & 99,73 & 11568 & 98,07 & 26 & 0,22 \\
\hline Чернігівська & 9285 & 96,13 & 9115 & 94,37 & 86 & 0,89 \\
\hline \multicolumn{7}{|l|}{ Micmo } \\
\hline Київ & 31777 & 99,70 & 31601 & 99,15 & 120 & 0,38 \\
\hline
\end{tabular}

при безсимптомному перебігу. Цю проблему необхідно вирішувати в рамках реалізації програмних заходів з планування сім'ї у ВІЛ-інфрікованих жінок шляхом консультування щодо попередження не лише небажаної вагітності, але й, можливо, тимчасового попередження бажаної вагітності за станом здоров'я. Звичайно, що вирішальне значення має бажання жінки, яка має бути поінформованою. У разі необхідності цю категорію жінок необхідно забезпечити засобами контрацепції одночасно із забезпеченням АРВ-препаратами.

Наступним проблемним питанням при організації проведення МП є ВІЛ-інфріковані вагітні споживачі ін'єкційних наркотиків (вагітні-CІH). За даними ДУ "Український центр контролю за соціально небезпечними хворобами МО3 України", у 2013 р. питома вага ВІЛ-інфрікованих вагітних-СІH, які отримали АРВ-профрілактику тільки під час пологів, що також знижує її ефективність, з причини неперебування під спостереженням лікаря-акушера- гінеколога, становила 17,5\%, що у 3,6 разу вище, ніж серед загальної кількості ВІЛ-інфрікованих вагітних (4,9\%). А частка тих, які зовсім не отримували АРВ-профрілактику, становить $12,7 \%$ серед ВІЛінфрікованих вагітних-СІH, серед загальної кількості - 3,8\% (вище у 3,3 разу), причому ця негативна тенденція не змінюється упродовж останніх років: у 2011 р. - відповідно 16,6\% та 4,3\% і 10,3\% та 4,5\%; у 2012 р. - відповідно 18,0\% та 4,9\% і 11,8\% та 4,2\%. Тобто третина ВІЛ-інфрікованих вагітнихСІН має високий ризик вертикальної трансмісії ВІЛ. Припускаємо, що вагітність у них була небажаною. Проблему, на нашу думку, необхідно вирішувати шляхом забезпечення контрацепцією разом із програмою замісної підтримуючої терапії (ЗПТ).

Одним із проблемних питань ефективності МП, яка пов'язана 3 неефективним плануванням сім'ї у ВІЛ-інфікованих жінок, є те, що в Україні збільшується кількість вагітних, які знали про свій ВІЛ- 
позитивний статус до настання вагітності, та пізнє звернення ВІЛ-інфікованих жінок за антенатальною медичною допомогою. За даними спеціального дослідження [2;7], 33,0\% матерів ВІЛінфрікованих дітей вперше зверталися до лікаряакушера-гінеколога тільки на момент пологів, 25\% матерів ВІЛ-інфрікованих дітей перед пологами мали високий рівень вірусного навантаження ВІЛ у плазмі крові, що відповідав активній стадії ВІЛінфекції (30 001-100 000 копій/мл) та стадії СНІДу (>100 000 копій/мл). У понад половини $(56,0 \%)$ жінок, які народили ВІЛ-інфікованих дітей, відмічена низька прихильність до АРТ. Вирішення означених проблем лежить виключно у площині планування сім'ї, тим більше, що у 48,0\% ВІЛ-інорікованих матерів, які народили ВІЛ-інфікованих дітей, вагітність була непланованою, а соціальний супровід під час проведення АРВ-профрілактики отримала тільки кожна четверта жінка (25,0\%), яка його потребувала [2;7].

Елективний кесарів розтин, як спосіб розродження і як одна з медичних технологій зниження ризику передачі ВІЛ від матері до дитини, був застосований 31,0\% ВІЛ-позитивним роділлям у 2013 р., $27,0 \%$ - у 2012 р., 22,0\% - у 2011 році. Позитивні тенденції цього показника вказують на поступове вирішення цієї ППМД, що сприятиме зменшенню кількості ВІЛ-інфрікованих дітей, народжених ВІЛ-позитивними матерями.

Зниження впливу акушерських чинників ПМД, таких як передчасні пологи, інвазивні втручання під час пологів (амніотомія, епізіотомія, акушерські щипці, інвазивний моніторинг плода тощо), тривалість безводного періоду (кожна година безводного періоду збільшує ризик ПМД на 2\%), пологи через природні пологові шляхи (порівняно з елективним кесаревим розтином), відсутність АРТ (збільшення ризику на 50\%), тривалість пологів, санація пологових шляхів, ускладнення кровотечею під час пологів, сприятиме ефективності ППМД [2].

У зв'язку з особливостями діагностики ВІЛінфекції у дітей, народжених ВІЛ-інфікованими жінками, усі такі діти після народження перебувають під диспансерним наглядом до моменту остаточного встановлення ВІЛ-статусу (18 місяців і старше). Показник чПМД - це частка дітей 3 ВІЛ-позитивним статусом, народжених ВІЛ- інфрікованими жінками, одного календарного року, яким виповнилося 18 місяців, від загальної кількості дітей, народжених ВІЛ-інфрікованими жінками у тому ж календарному році. Діти, у яких діагноз ВІЛ-інфекції залишився в стадії підтвердження, не враховуються при обчисленні показника чПМД.

За результатами серологічних досліджень, показник ЧПМД в Україні за період 2010-2014 рр. знизився на 31,7\%: 2010 р. - 6,34\% (діти народилися у 2008 р.), 2014 р. - 4,31\% (діти народилися у 2012 р.). Однак порівняно з 2013 р. показник чПМД збільшився з 3,7\% до 4,31\%, що вказує на необхідність посилення заходів ППМД, зокрема 3 планування сім'ї у ВІЛ-позитивних жінок.

Показник низької прихильності матерів до АРBпрофрілактики за результатами соціологічного дослідження становить 56\%, який майже збігається 3 показником непланованої вагітності (48\%) [2;5], вказує на необхідність застосування цільових заходів щодо планування сім'ї для ВІЛ-інфікованих жінок для попередження подібних випадків з метою зменшення кількості випадків перинатальної трансмісії ВІЛ.

Кількість ВІЛ-позитивних дітей, народжених ВІЛ-позитивними жінками, які перебувають на обліку в медичних закладах, що здійснюють медичний нагляд за ВІЛ-позитивними особами, зростала включно до 2013 р.: у 2010 р. - 2612 осіб, у 2011 р. - 2722, у 2012 р. - 2929, у 2013 р. - 3129 осіб. У 2014 р. кількість таких дітей дещо зменшилася і становить 3036 дітей. Кількість дітей, народжених ВІЛ-інфрікованими жінками, можливо суттєво зменшити за рахунок попередження небажаних вагітностей шляхом ефективної діяльності служби планування сім"ї з ВІЛ-інфрікованими жінками.

\section{Висновки}

Таким чином, основними проблемами ППМД в Українієнепланованість вагітностіу ВІЛ-інфікованих жінок та пов'язана з цим низька їх прихильність до своєчасного обстеження на ВІЛ, до необхідності допологового нагляду, АРВ-профілактики під час вагітності, своєчасної госпіталізації на пологи, обстеження новонародженого та оптимального догляду за ним; пізні стадії ВІЛ-інфрекції у вагітних; споживання ін'єкційних наркотиків; ризикована статева поведінка під час вагітності.

\section{Список літератури}

1. Аборт - предиктор порушень репродуктивного здоров'я жінки. [Електронний документ] / І.Б. Вовк О.І. Тимченко, О.О. Ревенько, О.М. Ревенько. - Режим доступу : http://health-ua.com/pics/pdf/ZU_2014_Akusher_1/44-47.pdf. Назва з екрану.

2. ВІЛ-інфекція в Україні : інфрорм. бюл. № 41 / МОЗ України. - Київ, 2014. - 95 с.

3. Державний центр статистики МОЗ України. 2014 рік. [Електронний документ]. - Режим доступу : http://www.moz. gov.ua - Назва з екрану.

4. Доклад о глобальных ответных мерах на ВИЧ/СПИД [Электронный документ] / ВОЗ, ЮНИСЕФ, ЮНЭЙДС. 2012. - Режим доступа : http://www.who.int/hiv/ru. - Название с экрана.

5. Комплексна зовнішня оцінка національних заходів з протидії СНІДу в Україні : зведений звіт / ВООЗ, Представництво ЮНЕЙДС в Україні. - Київ, 2009. - 240 с. 
6. Програма дій, адаптована на Міжнародній конференції з питань народонаселення та розвитку / Фонд народонаселення ООН. - К., 1997. - 56 с.

7. Соціально-демографрічні та медичні детермінанти ризику передачі ВІЛ від матері до дитини в Україні / Н. М. Нізова, В. А. Марциновська, І. В. Кузін [та ін.]. - Київ, 2013. - 68 с.

\author{
АНАЛИЗ СОСТОЯНИЯ ПРОФИЛАКТИКИ ПЕРЕДАЧИ ВИЧ ОТ МАТЕРИ К РЕБЕНКУ \\ А.Н. Дзюба' ${ }^{1}$ Н.Я. Жилка², Е.А. Орлова ${ }^{3}$

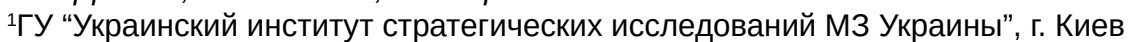 \\ ${ }^{2}$ Национальная медицинская академия последипломного образования имени П.Л. Шупика, \\ г. Киев, Украина \\ ${ }^{3}$ Министерство здравоохранения Украины, г. Киев
}

Цель: определить состояние системы профилактики передачи ВИЧ от матери к ребенку, мероприятий по планированию семьи для ВИЧ-инфицированных женщин.

Материалы и методы. В исследовании изучались материалы медицинской и статистической документации, использованы статистический, аналитический, организационный и концептуальный методы.

Результаты. Установлено, что основными проблемами передачи ВИЧ от матери ребенку в Украине являются непланирование беременности и связанная с этим низкая приверженность к своевременному обследованию на ВИЧ, к дородовому наблюдению, АРВ-профиллактике во время беременности, своевременной госпитализации на роды, обследованию новорожденного и оптимальному уходу за ним; поздние стадии ВИЧ-инфекции у беременных; потребление инъекционных наркотиков; рискованное половое поведение во время беременности.

Выводы. Профилактику вертикальной передачи ВИЧ в Украине можно существенно улучшить за счет оптимизации деятельности службы планирования семьи и улучшения оказания медико-социальной помощи ВИЧ-инфицированным женщинам.

КЛЮЧЕВЫЕ СЛОВА: ВИЧ-инфекция, планирование семьи, женщины, дети, профилактика передачи ВИЧ от матери к ребенку.

\title{
ANALYSIS OF PREVENTION OF HIV TRANSMISSION FROM MOTHER TO CHILD O.M. Dzyuba ${ }^{1}$, N.Ya. Zhylka², O.O. Orlova ${ }^{3}$ \\ ${ }^{1} \mathrm{PE}$ “Ukrainian Institute of Strategic Researches MHC of Ukraine", Kyiv \\ ${ }^{2}$ National Medical Academy of Postgraduate Education named after P.L. Shupyk, Kyiv, Ukraine \\ ${ }^{3}$ Ministry of Health of Ukraine, Kyiv
}

Purpose: to define of the system condition of prevention of HIV transmission from mother to child, implementation of family planning for HIV-infected women.

Material and methods. In this study are used: statistical, analytical, organizational and conceptual methods from medical documents and official information.

Results. The study determined that the major problems of HIV transmission from mother to child in Ukraine is unplanned pregnancy of HIV-infected women and associated with this low commitment to their timely HIV testing, prenatal surveillance, ARVP during pregnancy, timely hospitalization for childbirth, examination of newborn and optimal care by him; late stages of HIV infection in pregnant women; injecting drug taking; risk sexual behavior during pregnancy.

Висновки. Профрілактику вертикальної передачі ВІЛ в Україні можливо суттєво покращити за рахунок оптимізації діяльності служби планування сім'ї та покращення надання медико-соціальної допомоги ВІЛінсрікованим жінкам.

Conclusions. Prevention of HIV transmission from mother to child in Ukraine may essential improving due to optimization of family planning service and improvement of health and social care for HIV-infected women.

KEY WORDS: HIV, family planning, women, child, prevention of HIV transmission from mother to child.

Рукопис надійшов до редакції 20.06.2015 р.

Відомості про авторів:

Дзюба Олександр Миколайович - д.мед.н., проф. кафедри неврології НМУ ім. О.О. Богомольця, заступник директора ДУ «Український інститут стратегічних досліджень МОЗ України»; тел. служб. +38 (044) 576-41-49. Жилка Надія Яківна - д.мед.н., с.н.с., заслужений лікар України, доц. кафредри акушерства, гінекології та перинатології Національної медичної академії післядипломної освіти імені П.Л. Шупика; тел. моб.: +38 0677908585. Орлова Олена Олександрівна - головний спеціаліст відділу акушерсько-гінекологічної допомоги управління материнства і дитинства департаменту медичної допомоги Міністерства охорони здоров'я України; тел. служб. +38 (044) 200-07-91. 